\title{
Improving the ability of writing advertising sentences in students
}

\author{
Amri As ${ }^{1}$, Ratu Wardarita ${ }^{2}$, Dessy Wardiah ${ }^{3}$ \\ ${ }^{1}$ SM P Negeri 14 OKU \\ ${ }^{2}$ Universitas PGRI Palembang
}

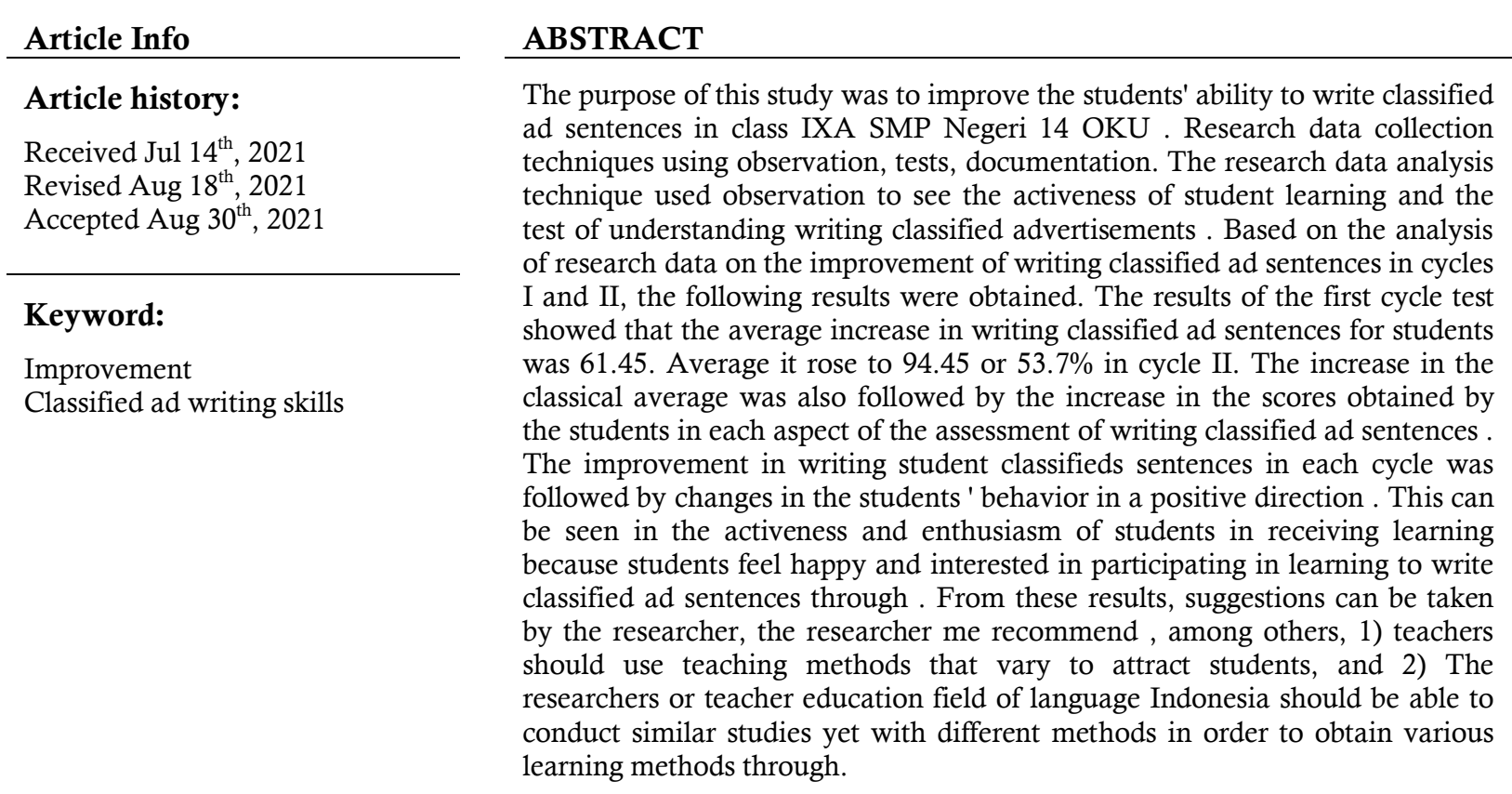

(C) 2021 The Authors. Published by IICET.

This is an open access article under the CC BY-NC-SA license (https://creativecommons.org/licenses/by-nc-sa/4.0

\section{Corresponding Author:}

Amri As.,

SMP Negeri 14 OKU

Email: amri.as1076@gmail.com

\section{Introduction}

In learning Indonesian at school, there are four language skills, namely listening, speaking, reading and writing skills. These four skills are closely related to the thought processes that underlie language.A person's language reflects his thoughts. Skills can only be acquired and mastered by practicing and practicing more. Speaking and listening (listening) are direct communication, while writing and reading activities are indirect communication.

According to [1], writing is a language skill that is used to communicate indirectly. Writing is a productive and expressive activity. In writing activities, writers must be skilled at utilizing graphology, language structure, and vocabulary. Writing skills will not dat a ng automatically but must go through a lot of exercise and regular practice. Learning to write that is given to students can be carried out in various forms, for example composing 
sentences using predetermined vocabulary, developing sentences into complete paragraphs, and arranging essay frameworks and developing them into essays. The writing activity exercise must also integrate listening, speaking and reading skills. In addition, it can be combined with making corrections to a friend's writing in terms of spelling and use of words or diction.

Activities carried out by students in writing can train students to develop logic, train imagination, train and hone creativity and train to express thoughts sequentially and coherently. Thus it can be said that writing is very important in life because a person's ideas and thoughts can be conveyed or communicated to others in written form. This means that readers can gain knowledge and information about the things the writer reveals so that they have benefits in the reader's life.

One of the writing activities that students can do in learning is writing classified ads. In writing classified advertisements, students must take advantage of the structure of the language, the accuracy of the information in classified ads and the mastery of vocabulary that can influence the listener or reader of the ad. In the process of learning to write classified advertisements, it is inseparable from written communication, namely making communicative sentences in the classified advertisements.

Lesson b ahasa Indonesia Class IX A half 1 SMP Negeri 14 OKU 2020/20211 academic year there are basic competencies writing language classified ads with short, dense, and clear. The learning objective is that students can register items to be written in classified advertisements in newspapers and can write classified ads in economical language. The expected success indicators are: 1) able to determine the object to be advertised; 2) able to abbreviate words according to classified advertising habits; 3) able to write classified ads in short, concise and clear language; 4) able to edit classified ads.

Classified advertisements are often referred to by several terms which are generally conveyed by the name of the column or column used by the media concerned. Usually classified ads are no more than 3-5 rows with an area of no more than one column [2]. Then there is another definition of classified ads, namely small advertisements (brief) which consist of only a few lines in a sentence. Classified ads are usually written in an objective, concise, honest and clear manner .

Through teaching in schools, students are expected to be able to make various forms of advertisements, including making sentences in classified ads. Making sentences in classified ads is very important to get information from the author to the reader. In learning activities, students have studied classified advertisements in accordance with the current Education Unit Level Curriculum, especially at SMP Negeri 14 OKU. In connection with this importance, researchers are interested in conducting research so that it can be seen the level of ability of class IX A students of SMP Negeri 14 OKU in writing sentences in classified ads. In addition, this learning is in accordance with the 2013 Curriculum for the competency standard of "Writing to reveal information in the form of classified advertisements" and the basic competence of "Writing classified ads in short, concise, and clear language". The desired indicators of this activity are (1) students are able to determine objects to be advertised, (2) students are able to abbreviate words according to the criteria for classified advertisements, (3) students are able to write classified advertisements in short, concise, and clear language, and (4) students are able to edit advertisements.

\section{Method}

The study, which was entitled the improvement of the ability to write classified ad sentences in class IXA students of SMP Negeri 14 OKU. Understanding is a process of thinking and learning using quantitative research methods. Descriptive method canbe interpreted as a problem- solving procedure investigated by describing or describing the condition of the subject or object of research (understanding writing classified ads ) at the present time based on the facts that appear or as they are. [3] quote, ability is being, being, being able, being able to do something properly and correctly according to what is expected. From some of the opinions above, it can be understood that what is meant by ability is the ability of students to do something that is done.

Research descriptive is the study of the simplest, compared with studies of other, because of the study 's researchers did not do anything against objects or areas studied. In this study,the researcher described the increase in students' ability to write classified ad sentences . Furthermore, determining the level of student ability in writing classified advertisements for class IXA students of SMP Negeri 14 OKU .

The results of the assessment are described in tabular form using benchmarks or standards from the opinion of [4], adjusted for the purpose of this study, namely measuring the increase in students' ability to write classified ad sentences. 
Table 1. Determination Benchmark P Increased K Capacity of Writing K alimat I clan B aris on S i swa $\mathrm{K}$ elas IXA SMP N e geri 14 OKU

\begin{tabular}{cccc}
\hline Percentage Interval & \multicolumn{2}{c}{ Value Change Scale to Five } & Information \\
\cline { 2 - 3 } & $0-4$ & EA & \\
\hline $85-100$ & 4 & A & Very well \\
\hline $75-84$ & 3 & B & Good \\
\hline $60-74$ & 2 & C & Enough \\
\hline $40-59$ & 1 & D & Less \\
\hline $0-39$ & 0 & E & Very less \\
\hline
\end{tabular}

\section{Results and Discussions}

Based on studies that support and strengthen the research results obtained as stated by the written word / language media. Writing is one of the language skills used in communication indirectly, it is not acquired naturally, but must go through a process of learning and practicing a lot and regularly [1]. The initial application of learning to write classified ad sentences was carried out in cycle I. Starting from the initial application, both the test and non-test results werestill lacking. This condition gradually increases after being given action during learning activities in cycle I and cycle II. As an initial application of learning, the teacher divides the class into six groups. In the action cycle I, there are three different advertising contexts that are made into classified ad sentences by each group. Every two groups get the same advertising context. Advertising context at the first meeting and based on the context given by the teacher.

To that end, the second cycle of the teachers made some improvements so that results are achieved by students in learning to write sentences classified ads through methods better. In addition, it is hoped that changes in student behavior will be better. In cycle II, the teacher made several improvements by providing a different advertising context from cycle I. In addition, in cycle II, the teacher also changed group members again. This is done so that students can work together with other friends too. Next, in the second cycle of the first meeting the teacher gave an example of the same advertising context to all groups.

Based on the second cycle of activities above, researchers concluded that the results achieved students in the test 's ability to write a sentence advertising line is better than the cycle I. Likewise, in the behavior of students who experienced a change in the positive direction from the first cycle to the second cycle.

[5] writes is the power or ability to communicate thoughts, perasaa $\mathrm{n}$, and willingness, so it can be understood by the reader. According to [6], writing activities are not the expected length of writing but the clarity of the content of the writing and the efficiency of using and choosing words. During the activity, students need to be aware that there are various possible ways of arranging or arranging words.

Based on the above opinion, the researcher concludes that writing is the ability to express ideas, opinions and feelings to other parties through written language or depicting graphic symbols that describe a language that is understood by someone, so that other people can read the graphic symbols, and they understand the language and the graphic symbols.

Classified ads are in the form of short notes consisting of only a few lines of sentences. Classified ads are usually found in a column with various offers, such as houses for rent / lease / sale, job vacancies, personal items offered for sale, or items being sought. Ali, " classified ads are small (short) advertisements consisting of only a few rows in a column; classified ads " [7].

Based on the above opinion, can pen eliti conclude that classified ads are ads published in the print media that is written with a small size, the length is about three to five rows in a column that the information most core to be known by enthusiasts or ad readers.

From the results of the study, it can be said that there is an increase in the students' ability in writing classified ad sentences in class IX A SMP Negeri $14 \mathrm{OKU}$ in each cycle. The results of the cycle I, namely the implementation of early doing action research class, showing a score average achieved at 61.45 which is in the category enough because the value is in the range 56-69. Furthermore, the results of the average score obtained in the second cycle of learning were 94.45 which was in the very good category because it was in the range 86-100. This means that learning in cycle II has increased by 33 from learning cycle I or an increase of $53.7 \%$. Based on the data collected can researchers conclude that the application of learning to write sentences classified ads have been successful in teaching writing competence classified ads in class IX A SMP Negeri 14 OKU, 
Then the ability to write classified ad sentences through aspects of the form of advertising increases from cycle I to cycle II. The results of the first cycle, namely the application of the initial classroom research action, showed that the average percentage achieved was $32.81 \%$ who were in the poor category. Sed a ngkan the second cycle of the average percentage obtained for $100 \%$ in the category very well. This shows that b e ntuk write sentences classified ads created by the students in the second cycle increased by $67.19 \%$ of the results of the first cycle,

The result of the assessment of the completeness of the contents of the line advertisement sentence in learning the ability to write classified ad sentences in class IXA students of SMP Negeri 14 OKU, from cycle I to cycle II has increased. The results of the first cycle, namely the application of the initial classroom research action, showed that the average percentage achieved was $75.78 \%$ in the good category. In the second cycle the average percentage obtained was $95.83 \%$ in the very good category. This shows that the completeness of the contents of the classified advertisement sentences made by students in the second cycle has increased by $20.05 \%$

$\mathrm{H}$ acyl cycle I. $\mathrm{H}$ acyl ratings aspects of the form discussed sentences classified ads on the learning ability to write sentences ads row from the first cycle to the second cycle increased. The results of the first cycle, namely the application of the initial classroom research action, showed that the average percentage achieved was $75.78 \%$ in the good category. In the second cycle the average percentage obtained was $87.5 \%$ in the very good category. This shows that the classified advertisement language made by students in cycle II has increased by $11.72 \%$ from the results of cycle I.

Based on the data- the data collected can researchers conclude that the application of learning the ability to write sentences classified ads have succeeded in learning to write sentences classified ads in class IX A SMP Negeri $14 \mathrm{OKU}$. It is known from the increase in the average student success in every aspect of assessment and the classical average in one class.

\section{Conclusions}

Based on the results of the study, the researchers concluded that there was an increase in the ability of students to write classified ad sentences in class IXA students of SMP Negeri 14 OKU. The ability to write classified ad sentences in class IX A SMP Negeri 14 OKU after participating in learning has increased. The increase that occurs can be seen based on the results of tests that have been carried out on class IX A SMP Negeri 14 OKU which includes cycle I and cycle II. Based on the test of the ability to write classified ad sentences carried out in the first cycle, the average value obtained by students classically was 61.45 . Meanwhile, in the second cycle it increased to 94.45 , there was an increase of 33 . The improvement in the students' ability to write classified ad sentences indicated that learning through was effective. The behavior of students in grade IX A SMP Negeri 14 OKU s fter follow pembelajara $n$ write sentences classifieds changes. This can be seen from observations, teacher diaries and student diaries, interviews, sociometry, and documentation.

\section{References}

Tarigan, Henry Guntur. 2008. Writing as a Language Skill. Bandung: Space.

Widyatama, Rendra. 2011. Ad Script Writing Techniques . Jakarta. Horizons.

Astuti, Tri Jani. 2013. Correlation Between the Ability to Understand the Meaning of Terms and the Ability to Read Comprehension of Class XI Students of SMA Negeri 12 Palembang . Palembang: PGRI University of Palembang.

Nurgiyantoro, Burhan. 2001. Assessment in Teaching Indonesian Language and Literature . Yogyakarta: BPFE.

Wardarita, Queen. 2004. Study of Indonesian Language and Literature . Palembang: Elmatera.

Purwo, Bambang Kaswanti. 1994. Principles of Teaching Indonesian in the Curriculum . Jakarta: Ditjen Dikdasmen.

Ali, Lukman, et al. 1998. Big Indonesian Dictionary. Jakarta: Balai Pustaka . 
